\title{
The Role of Vitamin D in Autoimmune Hepatitis
}

\author{
Khanh vinh quoc Luonga, ${ }^{a}$, Lan Thi Hoang Nguyen ${ }^{\mathrm{a}}$
}

\begin{abstract}
Autoimmune hepatitis is an inflammation of the liver characterized by the presence of peri-portal hepatitis, hypergammaglobulinemia, and the serum autoantibodies. The disease is classified into 2 distinct types according to the nature of auto-antibodies. Disturbances of the calcium-parathyroid hormone-vitamin D axis are frequently associated with chronic liver disease. Patients with AIH have a high prevalence of vitamin D deficiency. Genetic studies have provided the opportunity to determine which proteins link vitamin D to AIH pathology, namely, the major histocompatibility complex class II molecules, vitamin $\mathrm{D}$ receptors, toll-like receptors, cytotoxic $\mathrm{T}$ lymphocyte antigen-4, cytochrome P450 CYP2D6, regulatory T cells (Tregs) and the forkhead/winged helix transcription factor 3. Vitamin D also exerts its effect on AIH through non-genomic factors, namely, mitogen-activated protein kinase signaling pathways, $\gamma \delta \mathrm{T}$ cells, interferon-gamma nitric oxide synthase, and reactive oxygen stress. In conclusion, vitamin D may have a beneficial role in $\mathrm{AIH}$ and improves liver function in concanavalin A-induced mouse AIH. Calcitriol is best used for AIH because it is the active form of a vitamin $\mathrm{D}_{3}$ metabolite and its receptors are present in sinusoidal endothelial cells, Kupffer cells, stellate cells of normal livers, and the biliary cell line.
\end{abstract}

Keywords: Calcitriol; Autoimmune hepatitis; Vitamin D

\section{Introduction}

The auto-immune hepatitis (AIH) is an inflammation of the liver characterized by the presence of peri-portal hepatitis, hypergammaglobulinemia, and serum autoantibodies. The

\footnotetext{
Manuscript accepted for publication July 18, 2013

${ }^{\mathrm{a}}$ Vietnamese American Medical Research Foundation, Westminster, California, USA

${ }^{\mathrm{b}}$ Corresponding author: Khanh vinh quoc Luong, 14971 Brookhurst St. Westminster, CA 92683, USA. Email: Lng2687765@aol.com

doi: http://dx.doi.org/10.4021/jocmr1505w
}

disease is classified into 2 distinct types according to the nature of autoantibodies [1,2]. Type $1 \mathrm{AIH}$ is characterized by anti-nuclear antibodies and/or smooth muscle antibodies in serum of northern European and American adults. Type 2 AIH is characterized by antibodies to the liver-kidney microsome type 1 (anti-LKM1) and primarily affects children between the ages of 2 and 14 years. Disturbances of the calcium-parathyroid hormone-vitamin D axis are frequently associated with chronic liver disease [3]. Vitamin D deficiency is common in non-cholestatic liver disease and correlates with disease severity [4]. AIH patients have low of vitamin D levels compared with control group [5]. Many studies have shown a significant effect of calcitriol on liver cell physiology. Calcitriol increases intracellular $\mathrm{Ca}^{2+}$ in rat hepatocytes [6] and controls DNA polymerase $\alpha$ activity. Calcitriol also controls cytoplasmic and nuclear protein kinase activity and promotes normal liver recovery after partial hepatectomy in rats [7]. Vitamin D has also been shown to have a detoxifying effect in human primary cultured hepatocytes by increasing the expression of $\mathrm{P}_{450}$ cytochromes (namely, CYP3A4, CYP2B6, and CYP2C9) [8]. Some studies have failed to detect VDR levels in the liver $[9,10]$. However, Gascon-Barre et al [11] demonstrated that human, rat, and mouse hepatocytes express very low nuclear vitamin $\mathrm{D}$ receptor (nVDR) mRNA and protein levels. In contrast, the sinusoidal endothelial, Kupffer, and stellate cells of normal livers; the biliary cell line; and rat hepatic neonatal epithelial cells all clearly expressed both nVDR mRNA and protein. Burger et al [12] demonstrated that calcitriol receptors were localized in the nucleus and widely distributed in normal human tissues, including those of the liver, kidney, thyroid, adrenal glands, gastrointestinal tract, breast, and skin. Calcitriol-binding proteins were present in liver nuclei isolated from mice, rabbits, chickens, and cultured rat hepatocytes [13]. A major metabolite of the vitamin $\mathrm{D}$ analog $1 \alpha$-hydroxy-vitamin $\mathrm{D}_{2}$, $1 \alpha, 24(\mathrm{~S})$-hydroxy-vitamin $\mathrm{D}_{2}$, has been identified in human liver cells in culture and strongly bind to the VDR [14]. Another report demonstrated the presence of VDR mRNA and protein in the livers of rats throughout life [15]. Both in vitro and in vivo models have demonstrated anti-proliferative and anti-fibrotic effects of calcitriol on liver fibrosis [16]. In concanavalin A (ConA)-induced mouse AIH, calcitriol sig- 
nificantly decreased the serum alanine transaminase (ALT) levels and markedly attenuated histological liver damage. The mechanism of action was associated with down-regulation of T-cell-mediated immunity and up-regulation of VDR gene expression [17]. Therefore, we will discuss the role of vitamin D in AIH.

\section{Genetic Factors Related to Vitamin D and Au- toimmune Hepatitis}

Studies have suggested that several genes in the major histocompatibility complex (MHC) region promote susceptibility to AIH. Located in the $\mathrm{MHC}$ region, human leukocyte antigen (HLA) genes have been implicated in AIH susceptibility. The genes of DRB1*0301 and DRB1*0401 are the susceptibility genes for type $1 \mathrm{AIH}$ in Caucasian American, northern European, and Italian patients [18-20]. The genes of DRB1*1501-DRB5*0101 protect against type 1 AIH in adult Caucasian American [18]. In a systematic review and metaanalysis study in Latin America, DQB1*02, DQB1*0603, DRB1*0405, and DRB1*1301 alleles were found to be risk factors for AIH. However, the DRB1*1302 and DQB $1 * 0301$ alleles were protective factors for AIH [21]. Calcitriol is known to stimulate phagocytosis but suppresses MHC class II antigen expression in human mononuclear phagocytes [22, 23].

Genetic studies provide an opportunity to link molecular variations with epidemiological data. DNA sequence variations, such as polymorphisms, exert both modest and subtle biological effect on AIH. Vitamin D exhibits immune-modulatory and anti-proliferative effects through VDR in diseases. Among a variety of VDR gene polymorphisms, BsmI and TaqI have been reported to be associated with autoimmune liver diseases. The FokI polymorphisms of VDR have been linked to AIH in German and Chinese populations [24, 25]. These reports suggest that alteration of VDR function may play a role in AIH.

Toll-like receptors (TLRs) are a group of glycoproteins that function as surface trans-membrane receptors and are involved in the innate immune responses to exogenous pathogenic microorganisms. Substantial evidence exists for an important role of TLRs in the pathogenesis and outcome of AIH. Healthy livers contain low mRNA of TLRs, such as TLR-1, TLR-2, TLR-4, TLR-8, TLR-9, TLR-10, and signaling molecules (MD-2 and My88) compared with other organs [26]. In ConA-induced mouse AIH models, TLRsMy88 signaling accelerates liver damage [27], a CpG-containg oligodeoxynucleotides (CpG-ODN) treatment decrease attenuates ConA-induced mouse AIH [28]. CpG-ODN is a ligand for TLR-9 that can be used as an immunological adjuvant. TLR-3 also has an important role in liver inflammation and injury in ConA-induced mouse AIH models. Treatment with ConA markedly increased TLR-3 expression on liver lymphocytes and sinusoidal endothelial cells, while disruption of the TLR-3 gene abolished ConA-induced liver injury [29]. In AIH, monocytes were higher in number, displayed higher levels of tumor necrosis factor alpha (TNF- $\alpha$ ), and expressed higher levels of TLR-4 compared with healthy controls [30]. Calcitriol has been shown to down-regulate intracellular TLR-2, TLR-4 and TLR-9 expression in human monocytes [31]. Interestingly, TLR activation results in the expression of the VDR and $1 \alpha$-vitamin D hydroxylase in human monocytes [32].

Cytotoxic T lymphocyte antigen-4 (CTLA-4) is involved in the regulation of $\mathrm{T}$ cells and upregulated during T-cell-mediated immune response. CTLA-4 functions as a negative regulator by binding to the $\mathrm{B} 7$ family co-stimulatory molecules on antigen-presenting cells with higher affinity than CD28. The CTLA-4 protein is known to have a role in the pathogenesis of AIH. Mice vaccinated with a plasmid containing the N-terminal region of mouse CTLA-4 and antigenic region of human CYP2D6 developed anti-LKM1 and anti-LC1 antibodies of the IgG2 subclass. In addition, the ALT levels have been correlated with both the presence of anti-LKM1/anti-LC1 antibodies and liver necroinflammation [33]. The mRNA levels of CTLA-4 were significantly decreased in patients with AIH compared with healthy controls [34]. CTLA-4 polymorphisms are associated with type 1 AIH in northern Caucasian European patients [35], Chinese patients [36], and Argentina children [37]; but not in Brazilian [38], Japanese [39], and German populations [40]. A meta-analysis study demonstrated that CTLA-4 gene +49A/G polymorphisms may be associated with susceptibility to type $1 \mathrm{AIH}$, while the A/A genotype may be protective against type $1 \mathrm{AIH}$ [41]. Calcitriol promoted regulatory $\mathrm{T}$ cell profiles by increasing CTLA-4 and interleukin-10 in mouse colon protein extracts [42]. Calcitriol also stimulated the expression of high levels of CTLA-4 in human CD4 ${ }^{+}$ CD25- T cells [43].

The cytochrome P450 (CYP) superfamily of enzymes is responsible for the oxidation, peroxidation, and/or reduction of vitamins, steroids, and xenobiotics, as well as the metabolism of drugs. CYP2D6, an important member of this superfamily, has been identified as the major auto-antigen in type $2 \mathrm{AIH}$ [44]. CYP2D6 is the major target auto-antigen of LKM-1 and is expressed on the plasma membrane of hepatocytes. This finding suggests a pathogenic role for anti-LKM-1 in liver injury [45]. Anti-LKM-1 sera inhibited CYP2D6 activity in vitro but did not inhibit cellular drug metabolism in vivo [46]. Antibodies against CYP2D6 conformational antigenic sites were present in LKM-1-positive sera [47]. The CYP2D6 index was significantly higher in patients with AIH compared with healthy controls [48]. Hintermann et al [49] demonstrated that epitope spreading is initiated at the immune-dominant epitope and later expands to neighboring and remote regions in patients with $\mathrm{AIH}$ and the CYP2D6 mouse model. Moreover, CYP2D6 is a potential 25 
Table 1. Genetic Factors Related to Vitamin D and Autoimmune Hepatitis (AIH)

Autoimune Hepatitis (AIH)
Vitamin D

Calcitriol suppresses MHC class II antigen expression in human mononuclear phagocytes and decreases interferon- $\gamma$-induced HLA-DR antigen expression in normal and transformed human keratinocytes.
Human Leukocyte Antigen (HLA)

$D R B 1 * 0301$ and $D R B 1 * 0401$ are the susceptibility genes for type $1 \mathrm{AIH}$ in Caucasian American, northern European, and Italian patients, whereas, DRB1*1501-DRB5*0101 protects against type $1 \mathrm{AIH}$ in adult Caucasian Americans.

$D R B 1 * 0405$ allele is associated with the susceptibility to type 1 AIH in Japanese, Chinese, and Mexican patients.

$D R B 1 * 1301$ is associated with type $1 \mathrm{AIH}$ in Argentine children, Brazilian patients, Venezuelan patients, and Indian patients.

Susceptibility to type $2 \mathrm{AIH}$ has been associated $D R B 1^{*} 07$ in Brazil, Germany, and Turkish children.

In a systematic review and meta-analysis study in Latin America, $D Q B 1 * 02, D Q B 1 * 0603$, $D R B 1 * 0405$, and $D R B 1 * 1301$ alleles were found to be risk factors for $\mathrm{AIH}$, while $D R B 1 * 1302$ and $D Q B 1 * 0301$ alleles were protective factors for $\mathrm{AIH}$.

Vitamin D Receptor (VDR)

BsmI and TaqI are reported to be associated with autoimmune liver diseases.

The FokI polymorphisms of VDR are linked to AIH German and Chinese populations.

Cytotoxic T lymphocyte antigen-4 (CTLA-4)

The mRNA levels of CTLAA were significantly decreased in patients with AIH compared with healthy controls.

Mice vaccinated with a plasmid containing the N-terminal regional of mouse CTLA- 4 and the antigenic region of human CYP2D6 developed anti-LKM1 and anti-LC1 antibodies of IgG2 subclass. In addition, the ALT levels correlated with both the presence of anti-LKM1/anti-LC1 antibodies and presence of liver necroinflammation.

CTLA-4 deficiency causes severe lympho-proliferative disorder and multi-organ autoimmunity, leading to massive tissue destruction and early death.

CTLA-4 Ig suppressed a lupus-like illness in mouse models and reduced the incidence of diabetes in NOD mice.

CTLA-4 polymorphisms are associated with type $1 \mathrm{AIH}$ in northern Caucasian European [53], Chinese patients, and Argentina children; but not in Brazilian, Japanese, German populations. A meta-analysis study demonstrated that CTLA -4 gene $+49 \mathrm{~A} / \mathrm{G}$ polymorphisms may be associated with the susceptibility to patients with type $1 \mathrm{AIH}$, while A/A genotype may be protective against type $1 \mathrm{AIH}$.

\section{Toll-like Receptors (TLRs)}

In ConA-induced mouse AIH models, TLRs-My88 signaling accelerates the liver damage, whereas a decrease in $\mathrm{CpG}$-containing oligodeoxynucleotides (CpG-ODN) treatment attenuates ConA-induced mouse AIH. CpG-ODN is a ligand for TLR-9 and is used as an immunological adjuvant.

LR-3 also has an important role in liver inflammation and jury in ConA-induced mouse AIH models.

In $\mathrm{AIH}$, monocytes were higher in number, displayed a higher tumor necrosis factor alpha (TNF- $\alpha$ ), and expressed high levels of TLR-4 compared with healthy controls.

\section{Cytochrome P450 Cyp2D6}

CYP2D6 is the major target auto-antigen of LKM-1 and expressed on plasma membrane of hepatocytes, suggesting a pathogenic role for anti-LKM-1 in liver injury as a trigger. Anti-LKM-1 sera inhibited CYP2D6 activity in vitro but did not inhibit cellular drug metabolism in vivo.

Antibodies against CYP2D6 conformational antigenic sites were present in LKM-1-positive sera.

Regulatory $T$ cells (Tregs) and the forkhead/winged helix transcription factor 3 (Foxp3) In humans, mutations in Foxp3 result in an auto-immune syndrome termed IPEX (immune dysregulation, polyendocrinopathy, enteropathy, X-linked syndrome), an X-linked immunodeficiency syndrome characterized by insulin-dependent diabetes, thyroiditis, massive $\mathrm{T}$ cell infiltration in multiple organs, and chronic wasting.

During active disease, $\mathrm{CD} 4{ }^{+} \mathrm{CD} 25^{\text {high }} \mathrm{T}$ cells were fewer, expressed low levels of Foxp3, and were less effective at inhibiting target cell proliferation in patients with $\mathrm{AIH}$ than healthy controls.

The Foxp3-positive cells were primarily located in hepatic lobular peri-sinusoidal spaces and the portal tract.

The frequency of Tregs was increased in AIH patients compared with control and correlated with the inflammatory activity of the liver.
Calcitriol promoted regulatory $\mathrm{T}$ cell profiles by increasing CTLA-4 and interleukin-10 in mouse colon protein extracts. Calcitriol also stimulated the expression of high levels of CTLA4 in human $\mathrm{CD}^{+}{ }^{+} \mathrm{CD} 25^{-} \mathrm{T}$ cells.

Calcitriol has been shown to down-regulate intracellular TLR-2, TLR-4 and TLR-9 expression in human monocytes. TLR activation results in the expression of the VDR and $1 \alpha$-vitamin D hydroxylase in human monocytes. Biliary epithelial cells show intense immune-reactivity for cathelicidin and VDR.

CYP2D6 is a potential 25 hydroxyvitamin D- $1 \alpha$-hydroxylase, which converts vitamin $\mathrm{D}_{3}$ into $25 \mathrm{OHD}$, and vitamin $\mathrm{D}$ 25-hydroxylase deficiency resulted in vitamin $\mathrm{D}$ deficiency. Human 25-hydroxyvitamin D-1 $\alpha$-hydroxylase mutations also cause vitamin D-dependent rickets type 1 .

Vitamin D supplement was associated with significantly increased Tregs frequency in apparent healthy individuals. Calcitriol can affect human immune responses by regulating Foxp3 expression in $\mathrm{CD}^{+} \mathrm{T}$ cells through direct VDR binding to the Foxp3 gene.

Calcitriol stimulated expression of high levels of CTLA-4 and Foxp 3 in activated T cells. 
hydroxyvitamin D-1 $\alpha$-hydroxylase, which converts vitamin $\mathrm{D}_{3}$ into 25OHD, and vitamin D 25-hydroxylase deficiency resulted in vitamin D deficiency [50]. Human 25-hydroxyvitamin D-1 $\alpha$-hydroxylase mutations also cause vitamin Ddependent rickets type 1 [51].

Regulatory $\mathrm{T}$ cells (Tregs) are a distinct lymphocyte with inhibitory properties that affect the activation of the immune system. Tregs are characterized by the expression of $\mathrm{CD}^{2} 5^{+}$and the forkhead/winged helix transcription factor 3 (Foxp3) [52]. During active disease, $\mathrm{CD}^{+} \mathrm{CD} 25^{\text {high }} \mathrm{T}$ cells were reduced in numbers, expressed low levels of Foxp3, and were less effective at inhibiting target cell proliferation in patients with AIH compared with healthy controls [5355]. The Foxp3-positive cells were primarily located in the hepatic lobular peri-sinusoidal spaces and portal tract. The frequency of Tregs was increased in AIH patients compared with control and correlated with the inflammatory activity of the liver [34, 56]. However, vitamin D supplementation was associated with a significantly increased Treg frequency in apparent healthy individuals $[57,58]$. Calcitriol can affect human immune responses by regulating Foxp3 expression in $\mathrm{CD}^{+} \mathrm{T}$ cells through direct VDR binding to the Foxp3 gene [59]. Calcitriol stimulated the expression of high levels of CTLA-4 and Foxp3 in activated T cells [43]. Taken together, calcitriol may have a role in $\mathrm{AIH}$ by inducing Foxp $3^{+}$regulatory $\mathrm{T}$ cells.

Table 1 summarizes the genetic factors associated with vitamin $\mathrm{D}$ and autoimmune hepatitis.

\section{The Non-Genetic Role of Vitamin D in Autoim- mune Hepatitis}

The mitogen-activated protein kinase (MAPK) pathways provide a key link between the membrane-bound receptors that receive these cues and changes in the pattern of gene expression. The MAPK pathways include the extracellular signal-regulated kinase (ERK) cascade, stress activated protein kinases/c-jun N-terminal kinase (SAPK/JNK) cascade, and p38 MAPK/RK/HOG cascade [60]. Activation of p38 MAPK may contribute to the pathogenesis of auto-immune disease via activation of the signal transduction and expression of cytokines and chemokines [61]. The activation of p38 MAPK signaling pathway was up-regulated in experimental AIH, and the inhibition of p38 MAPK reduced hepatic inflammation and injury [62]. IL-17 contributes to the pathogenesis of AIH via induction of MAPK signaling pathway [63]. Apolipoprotein A2 (Apo A2) suppressed ConA-induced hepatitis by inhibiting the phosphorylation of ERK1/2 and cjun and reduced the intra-hepatic infiltration of inflammatory cells [64]. By regulating VDR mRNA expression, the p38 MAPK pathway participates in the mediation of calcium signals and affects lipid accumulation in mouse pre-adipocytes [65]. Zhang et al [66] demonstrated that the up-regulation of MAPK phosphatase 1 by vitamin D inhibited LPS-induced p38 activation and cytokine production in monocytes and macrophages.

$\mathrm{T}$ lymphocytes recognize foreign antigen by means of their surface receptor. According to the receptor type, T cells may be divided into $\alpha \beta$ and $\gamma \delta$ subsets. In peripheral blood, $\gamma \delta \mathrm{T}$ cells represent a small number of T cells. However, $\gamma \delta \mathrm{T}$ cells may play important roles in the pathogenesis of AIH. An elevation in the relative and absolute counts of $\gamma \delta \mathrm{T}$ cells in the peripheral and portal areas of patients with $\mathrm{AIH}$ has been detected [67]. $\gamma \delta \mathrm{T}$ cells in AIH patients were more numerous and had higher interferon-gamma (IFN- $\gamma$ ) and granzyme B production than healthy controls [53]. AIH children have an expansion and activation of $\gamma \delta \mathrm{T}$ cells in the peripheral blood [68]. The cytotoxic potential of $\gamma \delta \mathrm{T}$ lymphocytes has been previously demonstrated [69]. In contrast, calcitriol significantly inhibits the pro-inflammatory activity of $\gamma \delta \mathrm{T}$ cells in a dose dependent fashion [70]. The production of calcitriol by macrophages within tuberculous lesions inhibits proliferation and CD44 expression in $\gamma \delta \mathrm{T}$ cells [71].

Most human $\mathrm{T}$ cell clones obtained from healthy donors produce IFN- $\gamma$, IL-2, IL-4, and IL-5 upon stimulation with various mitogens. Soluble liver antigen-specific IFN- $\gamma$ responses were significantly more frequent in AIH patients than controls [72]. IFN- $\gamma$ is positively correlated with transaminase levels and decreases with immune-suppressive treatment or disease remission [73, 74]. Overexpression of IFN- $\gamma$-inducible protein 10 was identified in the liver of patients with type $1 \mathrm{AIH}$ [75]. The production of IFN- $\gamma$ is required for pathogenesis in a mouse model of fulminant liver inflammation and murine model of hepatitis [76, 77]. Additionally, calcitriol decreased serum ALT levels, markedly attenuated the histological liver damage, and caused a reduction of IFN- $\gamma$ in ConA-induced hepatitis [17]. Calcitriol inhibits CD40-induced IFN- $\gamma$ and immune-modulatory activity in human monocytes [78] and is a potent suppressor of IFN- $\gamma$-mediated macrophage activation [79].

Nitric oxide (NO) is involved in host defense reactions and plays a key role in the pathophysiology of vascular disorders. NO production in both sera and liver tissue increased after liver injury induced by delayed-type hypersensitivity to picryl chloride [80]. Animals pretreated with the inducible NO synthase (iNOS) inhibitor, L-N(6)-(1-iminoethyl)-lysine (L-NIL) had significantly increased serum ALT levels compared with animals challenged with ConA alone. However, pretreatment with NO donor molsidomine dramatically decreased ALT levels in L-NIL-pretreated animals [81]. This result suggests both endogenous and exogenous NO protect liver against $\mathrm{CoA}$-induced liver injury. Increased iNOS expression and nitrotyrosine accumulation was correlated with the histological severity of AIH [82]. Calcitriol-produced by macrophages may provide protection against the oxidative injuries caused by NO burst. Calcitriol is known to inhibit lipopolysaccharides (LPS)-induced immune activation in 
Table 2. Summary of the Non-Genomic Role of Vitamin D in Autoimmune Hepatitis

\begin{tabular}{|c|c|}
\hline Autoimmune Hepatitis (AIH) & Vitamin D \\
\hline $\begin{array}{l}\text { The mitogen-activated protein kinase (MAPK) signaling pathways } \\
\text { The activation of p } 38 \text { MAPK signaling pathway was up-regulated in } \\
\text { experimental AIH, and the inhibition of p } 38 \text { MAPK reduced hepatic } \\
\text { inflammation and injury. } \\
\text { IL-17 contributes to the pathogenesis of AIH via the induction of } \\
\text { MAPK signaling pathway. } \\
\text { Apolipoprotein A2 (Apo A2) suppressed ConA-induced hepatitis by } \\
\text { inhibiting the phosphorylation of ERK } 1 / 2 \text { and cJun and reduced the } \\
\text { intra-hepatic infiltration of inflammatory cells. }\end{array}$ & $\begin{array}{l}\text { Up-regulation of MAPK phosphatase } 1 \text { by vitamin D inhibited LPS- } \\
\text { induced p } 38 \text { activation and cytokine production in monocytes and } \\
\text { macrophages. }\end{array}$ \\
\hline $\begin{array}{l}\gamma \delta \text { T cells } \\
\text { An elevation in the relative and absolute counts of } \gamma \delta \mathrm{T} \text { cells in } \\
\text { peripheral and portal areas of patients with AIH. } \\
\text { AIH children are associated with an expansion and activation of } \gamma \delta \mathrm{T} \\
\text { cells in the peripheral blood. }\end{array}$ & $\begin{array}{l}\text { Calcitriol significantly inhibits the pro-inflammatory activity of } \gamma \delta \mathrm{T} \\
\text { cells in a dose dependent fashion. }\end{array}$ \\
\hline $\begin{array}{l}\text { Interferon-gamma (IFN- } \gamma \text { ) } \\
\text { Soluble liver antigen-specific IFN- } \gamma \text { responses were significantly more } \\
\text { frequent in AIH patients. This response was positively correlated with } \\
\text { transaminase levels and decreases with immune-suppressive treatment } \\
\text { or disease in remission state. } \\
\text { Production of IFN- } \gamma \text { is needed for the pathogenesis in a mouse model of } \\
\text { fulminant liver inflammation and murine model of hepatitis. }\end{array}$ & $\begin{array}{l}\text { Calcitriol decreased the serum ALT levels and markedly attenuated the } \\
\text { histological liver damage, and reduction of IFN- } \gamma \text { in ConA-induced } \\
\text { hepatitis. } \\
\text { Calcitriol inhibits CD } 40 \text {-induced IFN- } \gamma \text { and immune-modulatory } \\
\text { activity in human monocytes and is a potent suppressor of IFN- } \gamma \text { - } \\
\text { mediated macrophage activation. }\end{array}$ \\
\hline $\begin{array}{l}\text { Reactive Oxygen Species (ROS) } \\
\text { The amount of ROS found in AIH livers was significantly higher than } \\
\text { in healthy human livers. } \\
\text { Markers of lipid peroxidation were significantly elevated in patients } \\
\text { with AIH compared with normal controls. } \\
\text { Red blood cell glutathione (GSH) concentrations were significantly } \\
\text { lower in AIH than normal controls, but plasma GSH peroxidase activity } \\
\text { was significantly higher in AIH patients with elevated ALT values } \\
\text { compared with normal controls. } \\
\text { Homologs of NADPH oxidases (NOXs) are major sources of ROS and } \\
\text { was expressed in human livers with stage } 2-3 \text { AIH. }\end{array}$ & $\begin{array}{l}\text { Vitamin D may reduce the extent of lipid peroxidation, induces SOD } \\
\text { activity in the hepatic antioxidant system in rats, enhances intracellular } \\
\text { GSH pools, and significantly reduces nitrite production induced by } \\
\text { lipopolysaccharide (LPS). } \\
\text { In rat centrilobular hepatocytes, a vitamin D-deficient diet induced a } \\
\text { significant increase in NADPH. }\end{array}$ \\
\hline $\begin{array}{l}\text { Nitric oxide synthase (NOS) } \\
\text { NO production in both serum and liver tissue increased in the liver } \\
\text { injury induced by delayed-type hypersensitivity to picryl chloride. } \\
\text { Both endogenous and exogenous NO protected liver against CoA- } \\
\text { induced liver injury. } \\
\text { Increased iNOS expression and nitrotyrosine accumulation correlated } \\
\text { with the histological severity of AIH. }\end{array}$ & $\begin{array}{l}\text { Calcitriol-produced by macrophages may provide protection against the } \\
\text { oxidative injuries caused by NO burst. } \\
\text { Calcitriol is known to inhibit lipopolysaccharides (LPS)-induced } \\
\text { immune activation in human endothelial cells. }\end{array}$ \\
\hline
\end{tabular}

human endothelial cells [83].

Reactive oxygen species (ROS) have been suggested to play a role in AIH. The amount of ROS found in AIH livers was significantly higher than in healthy human livers [84]. Markers of lipid peroxidation, plasma malondialehyde and 8 -isoprostane, were significantly elevated in patients with AIH patients compared with normal controls [85]. The red blood cell glutathione (GSH) concentrations were significantly lower in AIH than normal controls. However, plasma GSH peroxidase activity was significantly higher in AIH patients with elevated ALT values compared with normal controls [86]. In AIH patients, oxidative stress and DNA damage are involved in the bile duct injury similar to primary biliary cirrhosis [87]. Moreover, homologs of NADPH oxidases (NOXs) are major sources of ROS and are expressed in human livers with stage 2-3 AIH [88]. Calcitriol enhances intracellular GSH pools and significantly reduces nitrite production induced by LPS [89]. In rat centrilobular hepatocytes, a vitamin D-deficient diet induced a significant increase in NADPH [90].

Table 2 summarizes the non-genomic role of vitamin D in autoimmune hepatitis.

\section{Conclusion}

The relationship between vitamin $\mathrm{D}$ and $\mathrm{AIH}$ has been discussed. Vitamin D may have a beneficial role in AIH. Genetic studies have provided the opportunity to determine what proteins link vitamin D to AIH pathology. Vitamin D also exerts its effect on AIH through non-genomic mechanisms. Calcitriol is useful in treating $\mathrm{AIH}$, because it is an active 
form of a vitamin $\mathrm{D}_{3}$ metabolite, and its receptors are present in the sinusoidal endothelial cells, Kupffer cells, and stellate cells of normal livers, and the biliary cell line.

\section{Conflict of Interest Statement}

The authors declare that they have no competing interests.

\section{Ethics Approval}

Not applicable.

\section{Funding}

The authors declare that they received no funding.

\section{References}

1. Krawitt EL. Autoimmune hepatitis. N Engl J Med. 2006;354(1):54-66.

2. Krawitt EL. Autoimmune hepatitis: classification, heterogeneity, and treatment. Am J Med. 1994;96(1A):23S$26 \mathrm{~S}$.

3. Moreira RO, Duarte MP, Farias ML. [Disturbances of calcium-PTH-vitamin D axis in chronic liver diseases]. Arq Bras Endocrinol Metabol. 2004;48(4):443-450.

4. Fisher L, Fisher A. Vitamin D and parathyroid hormone in outpatients with noncholestatic chronic liver disease. Clin Gastroenterol Hepatol. 2007;5(4):513-520.

5. Saron ML, Godoy HT, Hessel G. Nutritional status of patients with biliary atresia and autoimmune hepatitis related to serum levels of vitamins A, D and E. Arq Gastroenterol. 2009;46(1):62-68.

6. Baran DT, Milne ML. 1,25 Dihydroxyvitamin D increases hepatocyte cytosolic calcium levels. A potential regulator of vitamin D-25-hydroxylase. J Clin Invest. 1986;77(5):1622-1626.

7. Rixon RH, Isaacs RJ, Whitfield JF. Control of DNA polymerase-alpha activity in regenerating rat liver by calcium and 1 alpha,25(OH)2D3. J Cell Physiol. 1989;139(2):354-360.

8. Drocourt L, Ourlin JC, Pascussi JM, Maurel P, Vilarem MJ. Expression of CYP3A4, CYP2B6, and CYP2C9 is regulated by the vitamin $\mathrm{D}$ receptor pathway in primary human hepatocytes. J Biol Chem. 2002;277(28):2512525132.

9. Stumpf WE, Sar M, Reid FA, Tanaka Y, DeLuca HF. Target cells for 1,25-dihydroxyvitamin D3 in intestinal tract, stomach, kidney, skin, pituitary, and parathyroid. Science. 1979;206(4423):1188-1190.
10. Clemens TL, Garrett KP, Zhou XY, Pike JW, Haussler MR, Dempster DW. Immunocytochemical localization of the 1,25-dihydroxyvitamin D3 receptor in target cells. Endocrinology. 1988;122(4):1224-1230.

11. Gascon-Barre M, Demers C, Mirshahi A, Neron S, Zalzal S, Nanci A. The normal liver harbors the vitamin D nuclear receptor in nonparenchymal and biliary epithelial cells. Hepatology. 2003;37(5):1034-1042.

12. Berger U, Wilson $\mathrm{P}$, McClelland RA, Colston K, Haussler MR, Pike JW, Coombes RC. Immunocytochemical detection of 1,25-dihydroxyvitamin D receptors in normal human tissues. J Clin Endocrinol Metab. 1988;67(3):607-613.

13. Duncan WE, Whitehead D, Wray HL. A 1,25-dihydroxyvitamin D3 receptor-like protein in mammalian and avian liver nuclei. Endocrinology. 1988;122(6):25842589.

14. Strugnell S, Byford V, Makin HL, Moriarty RM, Gilardi R, LeVan LW, Knutson JC, et al. 1 alpha,24(S)dihydroxyvitamin D2: a biologically active product of 1 alpha-hydroxyvitamin D2 made in the human hepatoma, Hep3B. Biochem J. 1995;310 ( Pt 1):233-241.

15. Segura C, Alonso M, Fraga C, Garcia-Caballero T, Dieguez C, Perez-Fernandez R. Vitamin D receptor ontogenesis in rat liver. Histochem Cell Biol. 1999;112(2):163167.

16. Abramovitch S, Dahan-Bachar L, Sharvit E, Weisman Y, Ben Tov A, Brazowski E, Reif S. Vitamin D inhibits proliferation and profibrotic marker expression in hepatic stellate cells and decreases thioacetamide-induced liver fibrosis in rats. Gut. 2011;60(12):1728-1737.

17. $\mathrm{Hu}$ XD, Jiang SL, Liu CH, Hu YY, Liu C, Sun MY, Chen $\mathrm{GF}$, et al. Preventive effects of 1,25-(OH)2VD3 against ConA-induced mouse hepatitis through promoting vitamin D receptor gene expression. Acta Pharmacol Sin. 2010;31(6):703-708.

18. Strettell MD, Donaldson PT, Thomson LJ, Santrach PJ, Moore SB, Czaja AJ, Williams R. Allelic basis for HLAencoded susceptibility to type 1 autoimmune hepatitis. Gastroenterology. 1997;112(6):2028-2035.

19. Czaja AJ, Strettell MD, Thomson LJ, Santrach PJ, Moore SB, Donaldson PT, Williams R. Associations between alleles of the major histocompatibility complex and type 1 autoimmune hepatitis. Hepatology. 1997;25(2):317323.

20. Teufel A, Worns M, Weinmann A, Centner C, Piendl A, Lohse AW, Galle PR, et al. Genetic association of autoimmune hepatitis and human leucocyte antigen in German patients. World J Gastroenterol. 2006;12(34):55135516.

21. Duarte-Rey C, Pardo AL, Rodriguez-Velosa Y, Mantilla RD, Anaya JM, Rojas-Villarraga A. HLA class II association with autoimmune hepatitis in Latin America: a meta-analysis. Autoimmun Rev. 2009;8(4):325-331. 
22. Tokuda N, Levy RB. 1,25-dihydroxyvitamin D3 stimulates phagocytosis but suppresses HLA-DR and CD13 antigen expression in human mononuclear phagocytes. Proc Soc Exp Biol Med. 1996;211(3):244-250.

23. Tokuda N, Mizuki N, Kasahara M, Levy RB. 1,25-Dihydroxyvitamin D3 down-regulation of HLA-DR on human peripheral blood monocytes. Immunology. 1992;75(2):349-354.

24. Vogel A, Strassburg CP, Manns MP. Genetic association of vitamin D receptor polymorphisms with primary biliary cirrhosis and autoimmune hepatitis. Hepatology. 2002;35(1):126-131.

25. Fan L, Tu X, Zhu Y, Zhou L, Pfeiffer T, Feltens R, Stoecker W, et al. Genetic association of vitamin D receptor polymorphisms with autoimmune hepatitis and primary biliary cirrhosis in the Chinese. J Gastroenterol Hepatol. 2005;20(2):249-255.

26. Mencin A, Kluwe J, Schwabe RF. Toll-like receptors as targets in chronic liver diseases. Gut. 2009;58(5):704720 .

27. Ojiro K, Ebinuma H, Nakamoto N, Wakabayashi K, Mikami Y, Ono Y, Po-Sung C, et al. MyD88-dependent pathway accelerates the liver damage of Concanavalin A-induced hepatitis. Biochem Biophys Res Commun. 2010;399(4):744-749.

28. Zhang H, Gong Q, Li JH, Kong XL, Tian L, Duan LH, Tong J, et al. CpG ODN pretreatment attenuates concanavalin A-induced hepatitis in mice. Int Immunopharmacol. 2010;10(1):79-85.

29. Xiao X, Zhao P, Rodriguez-Pinto D, Qi D, Henegariu O, Alexopoulou L, Flavell RA, et al. Inflammatory regulation by TLR3 in acute hepatitis. J Immunol. 2009;183(6):3712-3719.

30. Longhi MS, Mitry RR, Samyn M, Scalori A, Hussain MJ, Quaglia A, Mieli-Vergani G, et al. Vigorous activation of monocytes in juvenile autoimmune liver disease escapes the control of regulatory T-cells. Hepatology. 2009;50(1):130-142.

31. Dickie LJ, Church LD, Coulthard LR, Mathews RJ, Emery P, McDermott MF. Vitamin D3 down-regulates intracellular Toll-like receptor 9 expression and Toll-like receptor 9-induced IL-6 production in human monocytes. Rheumatology (Oxford). 2010;49(8):1466-1471.

32. Liu PT, Stenger S, Li H, Wenzel L, Tan BH, Krutzik $\mathrm{SR}$, Ochoa MT, et al. Toll-like receptor triggering of a vitamin D-mediated human antimicrobial response. Science. 2006;311(5768):1770-1773.

33. Lapierre P, Djilali-Saiah I, Vitozzi S, Alvarez F. A murine model of type 2 autoimmune hepatitis: Xenoimmunization with human antigens. Hepatology. 2004;39(4):1066-1074.

34. Okumura A, Ishikawa T, Sato S, Yamauchi T, Oshima H, Ohashi T, Sato K, et al. Deficiency of forkhead box P3 and cytotoxic T-lymphocyte-associated antigen-4 gene expressions and impaired suppressor function of CD4(+)CD25(+) $\mathrm{T}$ cells in patients with autoimmune hepatitis. Hepatol Res. 2008;38(9):896-903.

35. Agarwal K, Czaja AJ, Jones DE, Donaldson PT. Cytotoxic T lymphocyte antigen-4 (CTLA-4) gene polymorphisms and susceptibility to type 1 autoimmune hepatitis. Hepatology. 2000;31(1):49-53.

36. Fan LY, Tu XQ, Cheng QB, Zhu Y, Feltens R, Pfeiffer T, Zhong RQ. Cytotoxic T lymphocyte associated antigen-4 gene polymorphisms confer susceptibility to primary biliary cirrhosis and autoimmune hepatitis in Chinese population. World J Gastroenterol. 2004;10(20):30563059.

37. Djilali-Saiah I, Ouellette P, Caillat-Zucman S, Debray D, Kohn JI, Alvarez F. CTLA-4/CD 28 region polymorphisms in children from families with autoimmune hepatitis. Hum Immunol. 2001;62(12):1356-1362.

38. Bittencourt PL, Palacios SA, Cancado EL, Porta G, Carrilho FJ, Laudanna AA, Kalil J, et al. Cytotoxic T lymphocyte antigen-4 gene polymorphisms do not confer susceptibility to autoimmune hepatitis types 1 and 2 in Brazil. Am J Gastroenterol. 2003;98(7):1616-1620.

39. Umemura T, Ota M, Yoshizawa K, Katsuyama Y, Ichijo T, Tanaka E, Kiyosawa K. Association of cytotoxic T-lymphocyte antigen 4 gene polymorphisms with type 1 autoimmune hepatitis in Japanese. Hepatol Res. 2008;38(7):689-695.

40. Schott E, Witt H, Pascu M, van Boemmel F, Weich V, Bergk A, Halangk J, et al. Association of CTLA4 single nucleotide polymorphisms with viral but not autoimmune liver disease. Eur J Gastroenterol Hepatol. 2007;19(11):947-951.

41. Miyake Y, Ikeda F, Takaki A, Nouso K, Yamamoto K. $+49 \mathrm{~A} / \mathrm{G}$ polymorphism of cytotoxic T-lymphocyte antigen 4 gene in type 1 autoimmune hepatitis and primary biliary cirrhosis: A meta-analysis. Hepatol Res. 2011;41(2):151-159.

42. Daniel C, Sartory NA, Zahn N, Radeke HH, Stein JM. Immune modulatory treatment of trinitrobenzene sulfonic acid colitis with calcitriol is associated with a change of a T helper (Th) 1/Th17 to a Th2 and regulatory T cell profile. J Pharmacol Exp Ther. 2008;324(1):23-33.

43. Jeffery LE, Burke F, Mura M, Zheng Y, Qureshi OS, Hewison M, Walker LS, et al. 1,25-Dihydroxyvitamin D3 and IL-2 combine to inhibit T cell production of inflammatory cytokines and promote development of regulatory T cells expressing CTLA-4 and FoxP3. J Immunol. 2009;183(9):5458-5467.

44. Christen U, Holdener M, Hintermann E. Cytochrome P450 2D6 as a model antigen. Dig Dis. 2010;28(1):8085.

45. Ma Y, Gregorio G, Gaken J, Muratori L, Bianchi FB, Mieli-Vergani G, Vergani D. Establishment of a novel radioligand assay using eukaryotically expressed cyto- 
chrome P4502D6 for the measurement of liver kidney microsomal type 1 antibody in patients with autoimmune hepatitis and hepatitis C virus infection. J Hepatol. 1997;26(6):1396-1402.

46. Mizutani T, Shinoda M, Tanaka Y, Kuno T, Hattori A, Usui T, Kuno N, et al. Autoantibodies against CYP2D6 and other drug-metabolizing enzymes in autoimmune hepatitis type 2. Drug Metab Rev. 2005;37(1):235-252.

47. Duclos-Vallee JC, Hajoui O, Yamamoto AM, Jacz-Aigrain E, Alvarez F. Conformational epitopes on CYP2D6 are recognized by liver/kidney microsomal antibodies. Gastroenterology. 1995;108(2):470-476.

48. Kimura M, Tatsumi KI, Tada H, Izumi Y, Kaneko A, Kato M, Masuzawa M, et al. Anti-CYP2D6 antibodies detected by quantitative radioligand assay and relation to antibodies to liver-specific arginase in patients with autoimmune hepatitis. Clin Chim Acta. 2002;316(12):155-164.

49. Hintermann E, Holdener M, Bayer M, Loges S, Pfeilschifter JM, Granier C, Manns MP, et al. Epitope spreading of the anti-CYP2D6 antibody response in patients with autoimmune hepatitis and in the CYP2D6 mouse model. J Autoimmun. 2011;37(3):242-253.

50. Lin CJ, Dardis A, Wijesuriya SD, Abdullah MA, Casella SJ, Miller WL. Lack of mutations in CYP2D6 and CYP27 in patients with apparent deficiency of vitamin D 25-hydroxylase. Mol Genet Metab. 2003;80(4):469472.

51. Fu GK, Lin D, Zhang MY, Bikle DD, Shackleton $\mathrm{CH}$, Miller WL, Portale AA. Cloning of human 25-hydroxyvitamin D-1 alpha-hydroxylase and mutations causing vitamin D-dependent rickets type 1. Mol Endocrinol. 1997;11(13):1961-1970.

52. Wan YY, Flavell RA. Regulatory T-cell functions are subverted and converted owing to attenuated Foxp3 expression. Nature. 2007;445(7129):766-770.

53. Ferri S, Longhi MS, De Molo C, Lalanne C, Muratori P, Granito A, Hussain MJ, et al. A multifaceted imbalance of $\mathrm{T}$ cells with regulatory function characterizes type 1 autoimmune hepatitis. Hepatology. 2010;52(3):9991007.

54. Li M, Zhuge HX, Zhu CW, Xu P, Iuo XR, Ye JZ, Zhu $\mathrm{W}$, et al. [CD4+CD25+high regulatory $\mathrm{T}$ cells in patients with autoimmune hepatitis]. Zhonghua Shi Yan He Lin Chuang Bing Du Xue Za Zhi. 2007;21(4):337-339.

55. Longhi MS, Hussain MJ, Mitry RR, Arora SK, Mieli-Vergani G, Vergani D, Ma Y. Functional study of CD4+CD25+ regulatory $\mathrm{T}$ cells in health and autoimmune hepatitis. J Immunol. 2006;176(7):4484-4491.

56. Peiseler M, Sebode M, Franke B, Wortmann F, Schwinge D, Quaas A, Baron U, et al. FOXP3+ regulatory T cells in autoimmune hepatitis are fully functional and not reduced in frequency. J Hepatol. 2012;57(1):125-132.

57. Prietl B, Pilz S, Wolf M, Tomaschitz A, Obermayer-
Pietsch B, Graninger W, Pieber TR. Vitamin D supplementation and regulatory $\mathrm{T}$ cells in apparently healthy subjects: vitamin D treatment for autoimmune diseases? Isr Med Assoc J. 2010;12(3):136-139.

58. Bock G, Prietl B, Mader JK, Holler E, Wolf M, Pilz S, Graninger WB, et al. The effect of vitamin D supplementation on peripheral regulatory $\mathrm{T}$ cells and beta cell function in healthy humans: a randomized controlled trial. Diabetes Metab Res Rev. 2011;27(8):942-945.

59. Kang SW, Kim SH, Lee N, Lee WW, Hwang KA, Shin MS, Lee SH, et al. 1,25-Dihyroxyvitamin D3 promotes FOXP3 expression via binding to vitamin D response elements in its conserved noncoding sequence region. J Immunol. 2012;188(11):5276-5282.

60. Hipskind RA, Bilbe G. MAP kinase signaling cascades and gene expression in osteoblasts. Front Biosci. 1998;3:d804-816.

61. Iwata Y, Wada T, Furuichi K, Sakai N, Matsushima K, Yokoyama H, Kobayashi K. p38 Mitogen-activated protein kinase contributes to autoimmune renal injury in MRL-Fas 1pr mice. J Am Soc Nephrol. 2003;14(1):5767.

62. Ma X, Jia YT, Qiu DK. Inhibition of p38 mitogen-activated protein kinase attenuates experimental autoimmune hepatitis: involvement of nuclear factor kappa B. World J Gastroenterol. 2007;13(31):4249-4254.

63. Zhao L, Tang Y, You Z, Wang Q, Liang S, Han X, Qiu $\mathrm{D}$, et al. Interleukin-17 contributes to the pathogenesis of autoimmune hepatitis through inducing hepatic interleukin-6 expression. PLoS One. 2011;6(4):e18909.

64. Yamashita J, Iwamura C, Sasaki T, Mitsumori K, Ohshima K, Hada K, Hara N, et al. Apolipoprotein A-II suppressed concanavalin A-induced hepatitis via the inhibition of CD4 $\mathrm{T}$ cell function. J Immunol. 2011;186(6):3410-3420.

65. Sun C, Qi R, Wang L, Yan J, Wang Y. p38 MAPK regulates calcium signal-mediated lipid accumulation through changing VDR expression in primary preadipocytes of mice. Mol Biol Rep. 2012;39(3):3179-3184.

66. Zhang Y, Leung DY, Richers BN, Liu Y, Remigio LK, Riches DW, Goleva E. Vitamin D inhibits monocyte/macrophage proinflammatory cytokine production by targeting MAPK phosphatase-1. J Immunol. 2012;188(5):2127-2135.

67. Martins EB, Graham AK, Chapman RW, Fleming KA. Elevation of gamma delta $\mathrm{T}$ lymphocytes in peripheral blood and livers of patients with primary sclerosing cholangitis and other autoimmune liver diseases. Hepatology. 1996;23(5):988-993.

68. Wen L, Peakman M, Mieli-Vergani G, Vergani D. Elevation of activated gamma delta $\mathrm{T}$ cell receptor bearing $\mathrm{T}$ lymphocytes in patients with autoimmune chronic liver disease. Clin Exp Immunol. 1992;89(1):78-82.

69. Nakata M, Smyth MJ, Norihisa Y, Kawasaki A, Shinkai 
Y, Okumura K, Yagita H. Constitutive expression of pore-forming protein in peripheral blood gamma/delta $\mathrm{T}$ cells: implication for their cytotoxic role in vivo. J Exp Med. 1990;172(6):1877-1880.

70. Chen L, Cencioni MT, Angelini DF, Borsellino G, Battistini L, Brosnan CF. Transcriptional profiling of gamma delta $\mathrm{T}$ cells identifies a role for vitamin $\mathrm{D}$ in the immunoregulation of the $\mathrm{V}$ gamma $9 \mathrm{~V}$ delta 2 response to phosphate-containing ligands. J Immunol. 2005;174(10):6144-6152.

71. Waters WR, Nonnecke BJ, Foote MR, Maue AC, Rahner TE, Palmer MV, Whipple DL, et al. Mycobacterium bovis bacille Calmette-Guerin vaccination of cattle: activation of bovine CD4+ and gamma delta TCR+ cells and modulation by 1,25-dihydroxyvitamin D3. Tuberculosis (Edinb). 2003;83(5):287-297.

72. Zhao Y, Zhang Y, Liu YM, Liu Y, Feng X, Liao HY, Vergani $\mathrm{D}$, et al. Identification of $\mathrm{T}$ cell epitopes on soluble liver antigen in Chinese patients with auto-immune hepatitis. Liver Int. 2011;31(5):721-729.

73. Ferreyra Solari NE, Galoppo C, Cuarterolo M, Goni J, Fernandez-Salazar L, Arranz LE, Garrote JA, et al. The simultaneous high expression of Valpha24, IFN-gamma and FoxP3 characterizes the liver of children with type I autoimmune hepatitis. Clin Immunol. 2010;137(3):396405.

74. Kamijo A, Yoshizawa K, Joshita S, Yoneda S, Umemura T, Ichijo T, Matsumoto A, et al. Cytokine profiles affecting the pathogenesis of autoimmune hepatitis in Japanese patients. Hepatol Res. 2011;41(4):350-357.

75. Nagayama K, Enomoto N, Miyasaka Y, Kurosaki M, Chen CH, Sakamoto N, Nakagawa M, et al. Overexpression of interferon gamma-inducible protein 10 in the liver of patients with type I autoimmune hepatitis identified by suppression subtractive hybridization. Am J Gastroenterol. 2001;96(7):2211-2217.

76. Robinson RT, Wang J, Cripps JG, Milks MW, English KA, Pearson TA, Gorham JD. End-organ damage in a mouse model of fulminant liver inflammation requires CD4+ T cell production of IFN-gamma but is independent of Fas. J Immunol. 2009;182(5):3278-3284.

77. Gorham JD, Lin JT, Sung JL, Rudner LA, French MA. Genetic regulation of autoimmune disease: BALB/c background TGF-beta 1-deficient mice develop necroinflammatory IFN-gamma-dependent hepatitis. J Immunol. 2001;166(10):6413-6422.

78. Almerighi C, Sinistro A, Cavazza A, Ciaprini C, Rocchi G, Bergamini A. 1Alpha,25-dihydroxyvitamin D3 inhibits CD40L-induced pro-inflammatory and immunomodulatory activity in human monocytes. Cytokine. 2009;45(3):190-197.

79. Helming L, Bose J, Ehrchen J, Schiebe S, Frahm T, Geffers R, Probst-Kepper M, et al. 1alpha,25-Dihydroxyvitamin D3 is a potent suppressor of interfer- on gamma-mediated macrophage activation. Blood. 2005;106(13):4351-4358.

80. Cao J, Xu Q, Koda A. Protective involvement of nitric oxide in the liver injury induced by delayed-type hypersensitivity to picryl chloride. Inflamm Res. 2000;49(11):578-583.

81. Ding JW, Wang K, Brems JJ, Gamelli RL. Protection against concanavalin A-induced hepatocyte apoptosis by molsidomine is time-dependent. J Am Coll Surg. 2004;198(1):67-77.

82. Sanz-Cameno P, Medina J, Garcia-Buey L, Garcia-Sanchez A, Borque MJ, Martin-Vilchez S, Gamallo C, et al. Enhanced intrahepatic inducible nitric oxide synthase expression and nitrotyrosine accumulation in primary biliary cirrhosis and autoimmune hepatitis. J Hepatol. 2002;37(6):723-729.

83. Equils O, Naiki Y, Shapiro AM, Michelsen K, Lu D, Adams J, Jordan S. 1,25-Dihydroxyvitamin D inhibits lipopolysaccharide-induced immune activation in human endothelial cells. Clin Exp Immunol. 2006;143(1):58-64.

84. Valgimigli L, Valgimigli M, Gaiani S, Pedulli GF, Bolondi L. Measurement of oxidative stress in human liver by EPR spin-probe technique. Free Radic Res. 2000;33(2):167-178.

85. Pemberton PW, Aboutwerat A, Smith A, Burrows PC, McMahon RF, Warnes TW. Oxidant stress in type I autoimmune hepatitis: the link between necroinflammation and fibrogenesis? Biochim Biophys Acta. 2004;1689(3):182-189.

86. Czuczejko J, Zachara BA, Staubach-Topczewska E, Halota W, Kedziora J. Selenium, glutathione and glutathione peroxidases in blood of patients with chronic liver diseases. Acta Biochim Pol. 2003;50(4):1147-1154.

87. Kadokawa Y, Ohba K, Omagari K, Akazawa S, Hayashida K, Ohnita K, Takeshima F, et al. Intracellular balance of oxidative stress and cytoprotective molecules in damaged interlobular bile ducts in autoimmune hepatitis and primary biliary cirrhosis: In situ detection of 8-hydroxydeoxyguanosine and glutathione-S-transferase-pi. Hepatol Res. 2007;37(8):620-627.

88. Jiang JX, Chen X, Serizawa N, Szyndralewiez C, Page P, Schroder K, Brandes RP, et al. Liver fibrosis and hepatocyte apoptosis are attenuated by GKT137831, a novel NOX4/NOX1 inhibitor in vivo. Free Radic Biol Med. 2012;53(2):289-296.

89. Garcion E, Sindji L, Leblondel G, Brachet P, Darcy F. 1,25-dihydroxyvitamin D3 regulates the synthesis of gamma-glutamyl transpeptidase and glutathione levels in rat primary astrocytes. J Neurochem. 1999;73(2):859866.

90. Bachelet M, Bader C, Merlot AM, Laborde K, Snarska J, Ulmann A. Cellular utilization of cytosolic NADPH in kidney and liver cells from rats fed a normal or a vitamin D-deficient diet. Cell Biochem Funct. 1983;1(1):25-29. 